\title{
Changes on the everyday living of people with spinal cord injury*
}

\author{
Mudanças no cotidiano de pessoas com lesão medular
}

Aline Gabriela Bega Ruiz'1, Mayckel da Silva Barreto², Thamires Fernandes Cardoso da Silva Rodrigues ${ }^{1}$, Jussara Simone Lenzi Pupulim ${ }^{1}$, Maria das Neves Decesaro ${ }^{1}$, Sonia Silva Marcon ${ }^{1}$

Objective: to apprehend the changes occurred on the everyday living of people with spinal cord Injury. Methods: qualitative research, anchored on the Symbolic Interactionism. Participants were 23 individuals with spinal cord injury intentionally selected, from the Family Health Strategy and a Paradesportive Association. Data were collected through semi structured interviews, in which were recorded, fully transcribed, organized on IRAMUTEQ software, and, later submitted to content analysis, thematic modality. Results: two thematic categories emerged, which show the experiences of incapacity, dependency and impotency feelings; difficulties in social, family and in sexual function adaptation, aside from pain advent, muscle spasms, pressure sores and urinary tract infection. Conclusion: changes experienced in the emotional, physiological and interactional context are complex and significant, however, there is chair appropriation, social adaptation and overcoming over time.

Descriptors: Spinal Cord Injuries; Wheelchairs; Disabled Persons.

Objetivo: apreender as mudanças ocorridas no cotidiano de pessoas com lesão medular. Métodos: estudo de natureza qualitativa, ancorado no Interacionismo Simbólico. Participaram do estudo 23 pessoas com lesão medular, selecionadas intencionalmente, a partir da Estratégia Saúde da Família e de uma Associação Paradesportiva. Dados coletados por meio de entrevistas semiestruturadas, as quais foram gravadas, transcritas na íntegra, organizadas no software IRAMUTEQ, e, posteriormente, submetidas à análise de conteúdo, modalidade temática. Resultados: emergiram duas categorias temáticas, as quais mostram a vivência de sentimentos de incapacidade, dependência e impotência; dificuldades de adaptação social, familiar e na área sexual, além do surgimento de dores, espasmos musculares, lesões por pressão e infecções do trato urinário. Conclusão: as mudanças experienciadas no âmbito emocional, fisiológico e interacional são complexas e significativas, porém, com o passar do tempo, ocorre apropriação da cadeira, adaptação social e superação.

Descritores: Traumatismos da Medula Espinal; Cadeiras de Rodas; Pessoas com Deficiência.

\footnotetext{
"Extracted from the dissertation "Vivências cotidianas da pessoa com lesão medular". Universidade Estadual de Maringá, 2017.

${ }^{1}$ Universidade Estadual de Maringá. Maringá, PR, Brazil.

${ }^{2}$ Faculdade de Filosofia, Ciências e Letras de Mandaguari. Mandaguari, PR, Brazil. 


\section{Introduction}

Annually, about 500 thousand people, all over the world are victimized by spinal cord injury, this grievance is characterized as a complex condition, of impact on everyday living of people affected, because modifies corporal image and social relations. The subjects become vulnerable to develop pressure sores, urinary tract infections and chronic pain. Most injuries, around $90.0 \%$, are caused by traumas, such as vehicles accidents, falls from great heights or violence ${ }^{(1)}$. In Brazil, these occurrences are considered as a public health problem ${ }^{(2)}$.

Spinal cord injury transforms the entire context of the affected person, such as work, recreation, social and personal life, requiring emotional, financial and physical adaptation to perform rehabilitation activities, demanding for effective family and social support to redefine priorities and reach life satisfaction ${ }^{(3)}$. Within necessary instruments to adapt to this condition, there is the wheelchair that for society symbolically represents physical, functional, sensorial and psychosocial incapacity, constituting as stigma, something that diminishes and promotes social segregation. Therefore, for the person that uses the wheelchair, it is characterized as an indispensable tool for the autonomy, which facilitates the overcoming limitations ${ }^{(4)}$.

Thus, based on the theory of Symbolic Interactionism, it was possible to comprehend the meanings attributed symbolically to the changes in the life and everyday living of individuals after spinal cord injury. Therefore, Symbolic Interactionism subsidizes the development of this study, with an important support on the basement of data discussion. This because, when using its presuppositions, it can be identified in what way the behavior of people with spinal cord injury, in consequence of a trauma, is influenced by the context in which social interactions occur and by the perception they have of them and of the environment ${ }^{(5)}$.

Differently from other countries that have research centers and lines of investigation directed to the social condition of disabilities, in Brazil are still scarce researches that involves this theme ${ }^{(6)}$. Also, in nursing context, the changes and adaptations in life of people with spinal cord injury has not been a focus of study, which concerns, because the nur- se, as an member of a multiprofessional team, must seek knowledge and scientific evidences and, from them, propose strategies that promote adaptation and rehabilitation ${ }^{(7)}$.

The lack of research difficult the comprehension of changes that occur in people after spinal cord injury, for that health professionals can adequate the care, according to each individual's demand, considering specificities, making the holistic and humanized assistance, promoting the rehabilitation and the quality of life ${ }^{(8)}$. Also, gather information about such changes, as well as understand the major necessities of this part of population, makes it important to foment the effectiveness of existing public policies and promote new ones.

In this regard, the objective of this study was to apprehend changes occurred on everyday living of people with spinal cord injury.

\section{Methods}

Qualitative research, performed with people with spinal cord injury, residents in a county on South of Brazil. For speech analysis, it was used as theoretical reference the precepts of Symbolic Interactionism, that aims to know how people realize their own changes occurred on everyday life after spinal cord injury, allows comprehending the meanings attributed to the people, relations and objects, in which are modified according to social interactions ${ }^{(5)}$.

For identification of the possible participants, it was contacted the team nurses of Family Health Strategy and the Adapted Physical Activity Program from the Physical Education Department from a higher education institution. The inclusion criteria were be at least 18, of any gender, diagnosed with spinal cord injury in at least two years and residents in the county. The only exclusion criteria was the participant not being found after three search attempts on different days and hours. The individuals were invited to participate in the study during a visit on sports court or in their residencies (accompanied by a community health agent). The people contacted accepted to participate in the study after explanation about the objecti- 
ves and type of participation desired. Only one person was not found.

The data was collected from January to July 2016, through semi structured interviews, previously scheduled or performed on the same day of contact, when there was availability and desire for it. The individual interviews had a mean duration of 90 minutes, they were performed only one time with each participant, at his or her home or in a reserved place close to the sports court. During the interviews, the deponents were invited to speak freely about experiences and difficulties: "Tell me about the personal, Family and social changes occurred in your life after the spinal cord injury occurrence", other questions were made according as the themes emerged. The search for new participants occurred until the moment in which was considered that the material obtained was wide-ranging and diverse, allowing DEEPENING about the phenomenon and, therefore, was sufficient for the reach of objective of the study ${ }^{(9)}$.

The speeches were recorded in digital media and fully transcribed. For data organization, it was used Interface de R pour les Analyses Multidimensionnelles de Textes et de Questionnaires (IRAMUTEQ) 0.7 Alfa 2.3.3.1 software $^{(10)}$, in which organizes and distributes graphically the words, facilitating comprehension. The use of it makes possible the realization of some types of analyses, such as the word cloud, similitude, descending hierarchical classification and factorial analysis ${ }^{(10)}$.

For this purpose, it is constructed a corpus textual, selecting sections from the deponents' speeches that correspond to the objective inquired and the software processes the textual production interpretation and the analysis. In this study, it was used word cloud type analysis, in which the occurrence of the words present in the corpus textual generates an image with a set of words combined according to frequency. The greater the word occurs in the cloud, greater is the amount of times the word has been repeated in the speeches $^{(10)}$ In the data analysis result presentation, it was chosen to use just nouns and verbs that reflect the aim of the study, since the other classes do not showed statistical significance. Therefore, the final corpus is constituted with 328 words and 269 (82.01\%) were used.

To construct the categories, convergence between words with identified greater frequency was performed by the software and the content analysis, thematic modality in three steps ${ }^{(11)}$. In pre-analysis, floating reading was performed, with later material exploration, which consisted on exhaustive reading, highlighting and gathering them, the emerging points by colors. Following, image coding was performed in which nuclei of meaning were apprehended and compiled, generating the thematic categories. Then, inference was performed from the data obtained and the theoretical reference assumed. In this phase, language context was analyzed and also the speaker's condition and their significance ${ }^{(11)}$. From result association obtained from word cloud and content analysis, two theoretical analyses emerged: Suddenly my life made a $180^{\circ}$ turn and Life after injury: relearn and exceedance.

Preserving the participant's anonymity, it was adopted a code number composed by the letter P, a number corresponding to study entry, M(man) or W(woman), individual's age, followed by the time of occurrence of spinal cord injury. The ones that accepted, signed the Free Informed Consent Form. The study was approved by the Research Ethics Committee of Maringá State University, according to report no 1.328.940.

\section{Results}

From the 23 people with spinal injury investigated, 16 were men. Aged 23 - 58 years and the average household income was 4 minimum wages. Seven participants studied more than eight years, eight were single, nine married, five separated and one widower. Five of them still had employment relationship and the rest did not practice professional activities and received government benefits, due to spinal cord in- 
jury consequences. Twelve participants had adapted vehicle, other six had cars without adaptations and the rest made use of collective transport.

Regarding to spinal cord injury etiology, 11 suffered automobilist accident (eight with motor bicycles), eight were injured by fire gun, two suffered from height falls, and one was a victim from a trampling and another from a tumor on the cervical region. The most evident injury's localization was on the twelfth thoracic vertebra (T12) present in seven interviewees. The average injury time was 14.6 years, being that the minimum time 2.7 years and the maximum 33 years.

According to word cloud (Figure 1), the most frequent words were: chair (111 times), stay (108 times), Family (79 times), friendship (71 times), depend (59 times), depend from another person(69 times), feel (52 times), pain (48 times), problem (46 times), and wheel (44 times). The size of the word "stay" is understandable when associated with wheelchairs, because, according to content analysis, it was apprehended that they were intimately related.

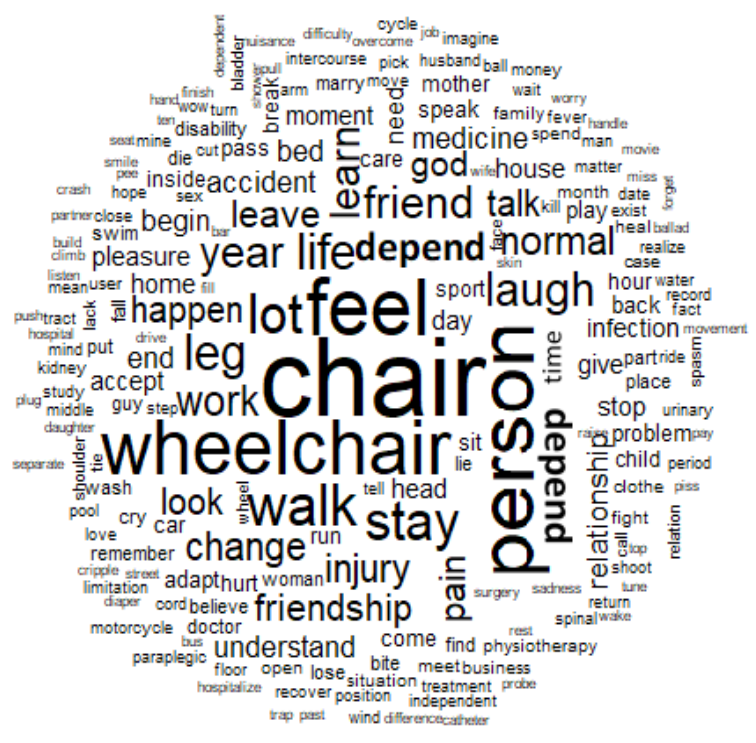

Figure 1 - Word cloud, IRAMUTEQ
The most frequent words supports the two categories identified on date analysis, in which allowed to know the everyday life of the participants, realities, changes, difficulties, yearnings, uncertainties, relearning processes and overcoming, mainly when incorporated the wheelchair as an indispensable instrument to their lives. These are described below.

\section{Suddenly my life made a 180 turn}

In this category, it was identified the main changes occurred in people's life after spinal cord injury, such as emotional alterations, anguish feelings, for depending on somebody, incapacity and denial, physical and physiological changes, development of pressure sores, pains, muscle spasms, urinary infections and sexuality alterations. It is painful to depend on someone else for everything, depend on carrying, steer and do (P1-M, 58y, SCI-20y). I couldn't accept to not walk anymore! It was very sad, painful and sorrowful (cry) because I depended on others (P7-W, 46y, SCI-33y). I worked and dealed with things! My husband only worked, received the money and brought home, I was the one who administrated it. Suddenly, everything changed, I started depending on them, on my family, on my husband, on my daughter for everything! It was a 180o turn (P6-W, 48y, SCI-8y).

The deponents appointed as aspects that complicated the physical activity practice the development of pressure sores, due to mainly the caregiver's unpreparedness, for not doing decubitus change and/or other cares. I didn't have so many complications as I have today, I have shoulder problems due to a bedsore. Stopped playing because I developed a coccyx injury, I was already admitted three times (P15-M, 52y, SCI-24y). I did four ulcer surgeries and it doesn't close, it complicates in practice, in life (P18-W, 46y, SCI-33y). I had multiple bedsores! It could putyour hand (cry). I stayed the same from the moment I woke up still I went to sleep (P7-W, 46y, SCI-33y).

Other physical changes that resulted in suffering and pain related to positioning, such as muscle spasms and infections mainly on the urinary tract were observed. Wheelchair users that stay only seated get constipation, abdominal and neuropathic pains. The pain interferes a lot in our life (P6-W, 48y, SCI-8y). I almost fell off the chair from so many spasms. Sometimes I notice sores, but I don't feel them; any minor thing hurts me (P9-W, 29y, SCI -10y). Because of the urinary infection, I 
was admitted five or six times. I realize the infection, when I have strong headaches and the urine has a strong smell (P23-M, 23y, SCI-6y).

Sexuality was another aspect that caused anguish and anxieties, because right after the injury, there was doubts regarding not being able to perform sexually and have frustration. I had two children, it was a challenge, because I didn't feel anything, I wanted to do sex, to experiment, kept getting into despair. I feel frustrated, I have this need like other people, even though I don't feel it in the body, I feel in the mind, keep imagining, because I had already a relationship before getting into the accident ( $\mathrm{P5}-\mathrm{W}, 52 \mathrm{y}, \mathrm{SCI}-32 \mathrm{y})$. The first question that comes to a man's mind is: I won't be able to do anything, now I will be a nobody? I died on the sexual relation part (P18-W, 52y, SCI-12y).

Some transformations in the social circle were reported by the deponents that practiced sports, such as making distance from old friends. Since, when participating in the Association, they met people and thus made new bonds, relationships and friendships that possibly in other situations it would not occur. Friends from before the accident only greet me they don't ask anything. The nicest friendships I have are with wheelchair users, that I met after I started doing sports (P19-M, 36y, SCI-12y). After the accident, my family became more united. When I got into the accident, only three friends were left, friends that I have were made through the wheelchair, through sports (P17-M, 40y, SCI-20y).

In synthesis, it could be observed the main transformations that emerged on everyday life of people with spinal cord injury, in which pathophysiological aspects and emotional and social alterations were involved. For this reason, this process had a significance to the participants such an intense moment of suffering, permeated with anguish and doubts. In some cases, there was detachment from old social circle, but on the other hand, gaps and opportunities for new friendships were made.

\section{Life after injury: relearn and overcoming}

This category identified the process that motivated learning and adaptation after spinal cord injury, that is to say, the subjects started to signify and (re)signify in different ways their lives. In order to adjust to new life condition, it was necessary to make modifications on daily life, incorporating activities and household alterations, to make the house accessible to the wheelchair user. I got married, I have my kids, do the dishes, wash and iron clothes, if needed, I clean the floor. We are adapting ourselves, learning, in the beginning, I couldn't get out of bed on to the chair, sit on the chair, I couldn't handle a chair, I had to learn, i went on adapting (P7-W, 48y, SCI-8y). I had to adapt, because I couldn't keep go in up and down the ramp to do stuff in the kitchen. (P6-W, 48y, SCI-8y). In the beginning, we didn't have (sexual) relation. Then I went to learn with the kids (other wheelchair users) to take the pills. Nowadays, I take the pills once in a while (P21-M, 23y, SCI-5y).

Adaptation allowed the individuals to undergo new experiences, return to labor and educational activities, in a way that suffering was replaced by overcoming and new meanings. I have to go on with life, I'm a wheelchair user! I overcame it! I live alone by choice, by freedom and independency. It was like this that I learnt to get around, got back to work, I have a car, got a social life, I was restored back to society. Today I know that this (paraplegia) isn't a defect (P2-M, 26y, SCI-7y). After the accident, I finished college, got married, built a home, today I live well, I travel, I achieve lots of things post-accident, because I never gave in (P13 -M, 35y, SCI-18y).

Initially, wheelchair had a meaning, of limitation and stigma that it started to transform after new social interactions with the object and the context. The acquisition of the wheelchair was reported as something fundamental, an object that becomes a part of the body. It expresses as an instrument full of meanings of facilitation of the daily activities, seen as the only way to get by. God in first place, then the wheelchair, it became everything for me, everything good! Then, on the first day, I saw (wheelchair) I thought: I don't even want to think about a chair! That was my reaction, I felt sadness, I thought: I will have to use that??! (P10-W, 38y, SCI-18y). The chair is my leg, gets me to wherever I want to go, leaves me at wherever I want to, without it, I'm nothing. It does not limit me from anything (P18-M, 34y, SCI-12y). It (chair) gets me to wherever I need to. In the beginning, I was a little perplexed for 4 years because of that (P20-M, 41y, SCI-15y).

It could be observed the initial difficulty in maneuvering the object previously unknown, therefore, over time, learning and adaptation, was possible to perform daily activities, such as domestic tasks, get back with sexual life, work, get married and, including, having kids.

\section{Discussion}

As a limitation of the study, there is the fact that it was carried out in an only encounter with the partici- 
pants, in which complicated the establishment of a bond with researcher-interviewer, this might have interfered on the answers' quality. Still, the majority of the participants were men, in which might have restricted the perception of everyday life changes to a gender perspective, mainly because men, as a matter of cause, present problems on addressing and revealing private aspects of life.

In any case, the results enrolled can direct the understanding about the investigated phenomenon and, thus, sensibilize health professionals about the changes occurred in the life of people with spinal cord injury and subsidize the development of actions that consider necessities and particularities of each one. At last, the findings challenge nursing, while social practice, to personally assuming the responsibility of acting with these people, encouraging them to early rehabilitation and to search strategies which favors inclusion, self-care and social participation.

From the results, it was observed that spinal injury established as a moment of transformation on the participants' lives and triggered different forms of reaction. Such changes involved primarily the necessity of pain and suffering overcome and, then, adaptation to a new routine, which included the usage of wheelchair as a form of independent locomotion. For this reason, wheelchair, before meaning to people as a bad thing, after established social interactions, started to have a new meaning.

Spinal cord injury is remarkable due to the gravity and the unpredictable nature of the situation, as consequence, bad perceptions and doubts are evoked regarding the future. Over time, the objects' meanings that surround a person are modified in an acceptance process. Right after the injury, people experiment social isolation in a phase of denial and shame of their lives, some, with time, start to accept and return to daily activities; social reintegration ${ }^{(4)}$.

According to the statements, it was identified that, early on the process, permanent dependency of the wheelchair and someone else to develop activities related to hygiene, alimentation, and locomotion among others provoked impotency, suffering and anguish feelings as symbolic meanings to spinal cord injury. Study performed in Santa Catarina, Brazil, with handicapped people, showed that physical and psychological dependency is present in people with spinal cord injury and, to exceed it, it is necessary support from a multiprofessional team, assisting on rehabilitation and coping ${ }^{(12)}$.

In this sense, it stands out the importance of the nurse to know the symbols attributed to spinal cord injury by people affected, putting themselves in their shoes, to assist in these individuals' adaptation to the new reality. It is highlighted the importance of these professionals' comprehension and, also, the multiprofessional team, about the symbolic meaning of everyday life with spinal cord injury in the individuals, as well as to know the changes arising from the injury, in a way to contribute to these individuals' daily life planning and on organization of health services.

Life post injury becomes a never-ending learning process, firstly, concerning on depending on others. Whereby post-trauma modifications occur, the way the person faces the situation, reflects on results obtained and can fragilize or potentialize adaptation and rehabilitation. In this sense, family and friends' support is fundamental in the process of overcoming the dependency condition ${ }^{(13)}$.

In the beginning of the injury, physiological transformations, such as the development of pain and dysfunctions, can not be controlled/tolerated, in which affects the person's humor and disposition, interfering on adaptation to the new life condition and to the development of daily activities. Although the injury interferes significantly on their self, causing symbols of alterations in social, physical, of habit, of humor among others; it is the pain that intensifies the suffering caused by trauma, and in which prevents he individual to perform daily activities ${ }^{(14)}$.

Participants in this study reported some physical conditions that affected significantly their lives after spinal cord injury apart from pain, such as urinary tract infections, muscle spasms and pressure sores. The hygiene discipline and usage of the right technique when performing the urethral catheterization of alleviation, for example, prevented possible complications that can complicate social and personal life. Thus, the multiprofessional team's performance in the process of relearning and social reintegration occurs through actions of education and training. It is necessary 
that these professionals assume the role of another in the interactional process and emphasize the person's capacity to perform self-care, aiming to independency and to healthy life, preventing secondary complications, such as urinary infections and pressure sores ${ }^{(15)}$.

Multicenter study, developed in Netherlands, with 282 people with spinal cord injury, showed that secondary health conditions, such as repeated urinary tract infection, pain, skeletal muscle spasms and pressure sores are common among them and are associated with less quality of life. Thereby, minimize secondary health condition impacts must be priority in long term care to these people ${ }^{(16)}$.

On the other hand, rehabilitation process not only assists recovery, but also the individual's social reintegration, for the individual restarts to develop community activities. It is urged that the multidisciplinary team stimulate the individuals to remedy difficulties, stimulating them to go back to their original background, and not only to perform intra-hospitals activities, as well as search for interactions amongst the community, thus promoting social reintegration ${ }^{(14)}$.

In consonance to this research, study showed that, although helping in independency, social interactions, new friendship opportunities and better life quality, and life satisfaction, sport also provides pains and sores ${ }^{(17)}$. These must be dealt with specialized follow-up, physical therapy and drug administration, because the pain enables he athlete's personal life, interfering even on night sleep. Adequate physical preparation constituted by before and after training stretching assists on pain reduction and prevents sores $^{(18)}$.

It is highlighted in this study that trust bonds help in sexuality, because in some cases physiological functions are not completely controlled. Study performed in Rio de Janeiro, Brazil, with people with spinal cord injury also stated that sexual changes constitutes a constant worry. In some cases, feminine and masculine condition lost is portrayed, self-image alterations, generating conflicts or even so separation of conjugal relationship. Self-image is symbolically modified and interferes on affective relationships, some people can not look at themselves in the mirror, fact that is explained by the aesthetic importance in sexual relations ${ }^{(8)}$.

Comparative study, developed in Czech Republic, with two groups of women with and without spinal cord injury, confirmed significant difference in sexual desire, lubrification and capacity to reach orgasm before and after injury. It was stated also alteration on performing sexual activity. Elements that affected negatively these women to perform sexual activity were less sensibility, spasms and mobility problems, reduced desire and pain ${ }^{(19)}$.

Therefore, to construct the path to overcoming, sexuality presents as a symbol to be modified and barrier to be surpassed. Study carried out in Paraná, Brazil, with 36 people with spinal cord injury, verified that rehabilitation is focused in motor capacities, and with sexuality poorly approached. Therefore, new possibilities of body interactions in the sexual aspect, in which must be discovered to prevent frustrations and, thus, preserve the individual's integrity ${ }^{(20)}$. The sexuality for these people gets a new meaning in life, since what it was before can't go back to being the same way, although through new interactions, sex starts to have a different meaning, reflecting on the person's form of acting.

It was observed that anterior affective bonds frequently did not stay, this because the wheelchair equipment symbolizes a functional dependency, stigmatizes the person, linking them to mental deficits, making them vulnerable to excluding processes. In the statements, it was observed that, in the beginning of spinal cord injury, the wheelchair symbolized disability even to the person with injury. Therefore, over time, it is conjectured the imminent necessity to go back to locomotion by themselves. Because of this and also because they find themselves in the overcoming phase, wheelchair starts to be seen as an extension of the body, starting to be normally incorporated in their daily lives and attributing another meaning, the meaning of freedom $^{(4)}$.

Interruption of daily activities in the beginning of the process, such as the fact of not playing soccer, riding a bicycle or even work, were mentioned by the participants as bad changes in their lives. The process of transformation has characteristics, as self-control and self-confidence, in which are determining factor for adaptation, with this, it 
is possible to experience vicissitudes relate to spinal cord injury in an efficient way, controlling the manifesting challenges.

It was observed that daily activities assists on independency and acceptance; since not depending on others is something symbolically important. Overcoming is a slow process, therefore over time, the individual's self and family do not contemplate neither value the limitations. Starts to attribute new meanings, not only in his or hers relation with the wheelchair, but also with the surrounding people. There is not a specific period of time for overcoming, which can vary from weeks to years. Spinal cord injury certainly brings consequences that makes fragile adaptation process, in which is experienced in a diverse and individualized way with their own self. Moreover, the time for adaptation to occur depends on life history, social support, confrontation strategies and the dimension of emerged consequences ${ }^{(8,14)}$.

\section{Conclusion}

The changes experienced in the emotional, physiological and interactional context are complex and significant, however, over time, there is chair appropriation, social adaptation and overcoming.

\section{Collaborations}

Ruiz AGB e Decesaro MN contributed to conception and project, analysis and interpretation, writing of the article and relevant critical analysis of the intellectual content. Barreto MS, Rodrigues TFCS, Pupulim JSL and Marcon SS collaborated with article writing, relevant critical analysis of the intellectual content and approval of the final version to be published.

\section{References}

1. Organização Mundial da Saúde (OMS). Health topics. Disabilities [Internet].2017 [cited2018Apr23].Available from: http://www.who.int/topics/disabilities/en/

2. Ministério da Saúde (BR). Secretaria da Atenção à Saúde. Diretrizes de atenção à pessoa com lesão medular. Brasília: Ministério da Saúde; 2013.
3. Pretz CR, Kozlowski AJ, Chen Y, Charlifue S, Heinemann AW. Trajectories of life satisfaction after spinal cord injury. Arch Phys Med Rehabil. 2016; 97(10):1706-13. doi: https://doi.org/10.1016/j.apmr.2016.04.022

4. Vasco CC, Franco MHP. Paraplegic individuals and the meaning-making process of the spinal cord injury in their lives. Psicol Cienc Prof. 2017; 37(1):119-31. doi: http://dx.doi.org/10.1590/1982-3703000072016

5. Blumer H. Symbolic Interacionism: perspective and method. London: University of California Press; 1969.

6. Nogueira GC, Schoeller SD, Ramos FRS, Padilha MI, Brehmer LCF, Marques AMFB. The disabled and public policy: the gap between intentions and actions. Ciênc Saúde Coletiva. 2016; 21(10):3131-42. doi: https://doi. org/10.1590/1413-812320152110.17622016

7. Azevedo TR, Valdevino SC, Costa KFM, Valdevino Neto J, Lira LGRSH, Martins KP. Acessibilidade física de pessoas com deficiência em hospitais públicos. Enferm Global [Internet]. 2015 [cited 2018 Sep 11]; 37(1):319-27. Available from: http://scielo.isciii.es/pdf/eg/v14n37/ pt_administracion3.pdf

8. Alvarez AB, Teixeira MLO, Branco EMSC, Machado WCA. The feelings of paraplegic clients with spinal cord lesion and their caregivers: implications to the nursing care. Ciênc Cuid Saúde [Internet]. 2013 [cited 2018 Apr 13]; 12(4):654-61. Available from: http://www.periodicos. uem.br/ojs/index.php/CiencCuidSaude/article/ view/18107

9. Robinson OC. Sampling in interview-based qualitative research: a theoretical and practical guide. Qual Res Psychol. 2014; 11(1):25-41. doi: https://doi.org/10.108 0/14780887.2013.801543

10. Jesus GJ, Oliveira LB, Caliari JS, Queiroz ACFL, Gir E, Reis RK. Difficulties of living with HIV/Aids: obstacles to quality of life. Acta Paul Enferm. 2017; 30(3):301-7. doi: http://dx.doi.org/10.1590/1982-0194201700046

11. Bardin L. Análise de conteúdo. Lisboa: Edições 70; 2011.

12. Brignol P, Schoeller SD, Silva DMGV, Boel JEW, Lopes SGL, Souza SS. Support network for persons with physical disabilities. Rev Enferm UERJ. 2017; 25:e18758. doi: http://dx.doi.org/10.12957/reuerj.2017.18758

13. Ferreira M, Guerra MP. Adjustment to spinal cord injury. Psicol Saúde Doenç [Internet]. 2014 [cited 2018 Mar 23]; 15(2):380-95. Available from: http://www.scielo.mec.pt/scielo.php?script=sci_ arttext\&pid=S1645-00862014000200005 
14. Silva VG, Jesus CAC. Biopsychosocial characteristics of patients with neuropathic pain following spinal cord trauma injury. Case reports. Rev Dor. 2015; 16(3):235-9. doi: http://dx.doi.org/10.5935/1806-0013.20150047

15. Teixeira SMM, Carvalho ALRF, Monteiro SSS, Cruz S. Selfcare assessment as an indicator for clinical supervision in nursing. Rev Rene. 2016; 17(3):356-62. doi: http:// dx.doi.org/10.15253/2175-6783.2016000300008

16. Adriaansen JJ, Ruijs LE, Van Koppenhagen CF, Van Asbeck FW, Snoek GJ, van Kuppevelt D, et al. Secondary health conditions and quality of life in persons living with spinal cord injury for at leastten years. J Rehabil Med [Internet]. 2016 [cited 2018 Jan 24]; 48(10):853-60. Available from: https://www.medicaljournals.se/jrm/content/ $\mathrm{html} / 10.2340 / 16501977-2166$
17. Zwierzchowskaa A, Zebrowskab A, Szkwaraa M. Sports activities and satisfaction of living of men after cervical spinal cord injury. Polish Ann Med. 2017; 24(2):205-8. doi: https://doi.org/10.1016/j.poamed.2017.03.009

18. Ferreira FA, Bussmann AJC, Greguol M. Incidence of injuries in wheelchair basketball players. Rev Ter Ocup USP. 2013; 24(2):134-40. doi: http://dx.doi. org/10.11606/issn.2238-6149.v24i2p134-140

19. Sramkova T, Skrivanova K, Dolan I, Zamecnik L, Sramkova K, Kriz J, et al. Women's sex life after spinal cord injury. Sex Med. 2017; 5(4):255-9. doi: https://doi. org/10.1016/j.esxm.2017.07.003

20. Torrecilha LA, Costa BT, Lima FB. Profile of sexuality in men with spinal cord injury. Fisioter Mov. 2014; 27(1):39-48. doi: http://dx.doi.org/10.1590/01035150.027.001.A004 